\title{
NOVA1 wt Allele
}

National Cancer Institute

\section{Source}

National Cancer Institute. NOVA1 wt Allele. NCI Thesaurus. Code C51290.

Human NOVA1 wild-type allele is located within $14 \mathrm{q}$ and is approximately $152 \mathrm{~kb}$ in length.

This allele, which encodes RNA-binding protein Nova-1, is involved in the regulation of RNA splicing or metabolism in a specific population of developing neurons. 